\title{
The Current Status of Collective Bargaining and Its Implications on Bottom-Line Performance in Nigeria Oil and Gas Industry
}

\author{
${ }^{1}$ Atoyebi Kehinde .O, ${ }^{2}$ Ogundeji, Musibau $. O,{ }^{3}$ Adekunjo Felix .O, \\ ${ }^{4}$ Kadiri Kayode Ibrahim, ${ }^{5}$ Taofiq Omotayo .O. \\ ${ }^{1,3,4}$ Lagos State University, Ojo Dept. Of Economics. \\ ${ }^{2}$ Lagos State University, Ojo
}

\begin{abstract}
This study empirically examine the current status of collective bargaining with particular focus on subject and workers rights and the extent to which they are complied with in oil and gas industry in Nigeria. In realization of the above, the research employed combination of primary and secondary source of data. This included survey design and reviews of relevant literatures.

Our findings suggest that the level of compliance on the part of employer is very low and this is because they are taking advantage of weak institution and legal framework due to the prevailing economy situation in the country. Also, we realized that the union are unable to compel employer to complied with relevant provisions of the collective bargaining agreement.

Based on our findings, we therefore recommend that the union need to continue to put interest of their workers first in the course of their negotiations and let the public know the right of workers. Also, the awareness on the part of workers is likely to reduce the likelihood of infringement, while it may reduce the hostility of the consuming public. We also advised that human rights groups and activist should be interested in public interest litigation such that they can take up cases on behalf of workers against employers who routinely breach provision of the relevant laws. The cost of litigation publicly generated will serve as a deterrent to the employers.
\end{abstract}

\section{Introduction:}

Collective bargaining is broadly defined as the alternative to and a replacement of individual week attempt at bargaining. To employers, it help to avoid comparability issues. To the state, peaceful industrial relations is an outcome of labour and management's efforts.

In a study by Sydney and Beatrice (1891) on collective bargaining in England, they saw collective bargaining as the main instrument used by actors employee and government institution in industry to sort out their differences through bargaining or negotiations, ultimately as a compromise between the claims of employers and linins to exercise unilateral control over the work situation.

More importantly, the international labour organisation has taken the preeminent authority on international labour standards by providing human rights instruments that guarantees and advocate the rights to collective bargaining through out the world. The (ILO) posited that collective bargaining should entail all negotiations alude takes place between employer, a group of employers of one or more employers' organisation. This negotiations include the determinant of the working conditions and terms of employment, regulation of relations between employers and workers in an organisation.

However, under Nigerian law, section of the Labour Act defines collective bargaining as the process of arriving at collection agreements. Nigeria's industrial relations systems are one of such British colonial legacies whose main feature is the voluntary machinery that has extended over a wide area of employment, from industry-wide collective bargaining and discussion between employers association and trade linions over terms and conditions of employment' (Okere, 2007).

But the major problem facing the collective bargaining issue in Nigeria is that of weak institutional and regulatory framework. Also, the new trend in industrial relations, is nothing other than the situation that has been promoted by the ascendancy of neo-liberalism as the framework of globalization trends. This trend emphasizes individualism instead of collectivism, hence the use of joint consultative council instead of collective bargaining to resolve industrial conflict. The implication of this is that employees are made to denounce participation in trade unionism thereby making the management to have unfettered control of the labour process and employment relationship. Some of these issues have fuelled dramatic and recurrent industrial action in Nigeria particularly in the upstream oil and gas industry. 
In the light of this background, this paper aims at examining the current status of collective bargaining in Nigeria. Also, to assess the degree of awareness of workers on subject of collecting bargaining particular, in oil and gas industry.

And on this note, the following research questions are provided to elicit response from the respondents.

- Are employee made to denounce participation in trade unionism?

- Can agreement on wages and condition of service be determined without collective bargaining?

- Is collective bargaining allowed in oil and gas industry?

$\mathrm{H}_{11}$ : There is no significant relationship between awareness of workers and subjects in collective bargaining agreement.

$\mathrm{H}_{12}$ : There is significant relationship between awareness of workers and subjects in collective bargaining agreement.

$\mathrm{H}_{21}$ : There is no significant relationship between observance and compliance with, collective bargaining in oil and gas industry in Nigeria.

The study is however, justified on the ground that international labour will have stand up to the task for the fundamental conventions to protect worker right all over the world. This study, however add to the existing literature on the current status of collective bargaining in Nigeria and its implication on the bottom line performance in oil and gas industry.

Summarily, the paper is structured as follows: Section one is the introduction, section review the existing literature and theoretical framework while section three dwells on stylized fact of oil and gas industry. Data analysis and findings are provided in section four. The last section gives the concluding remark and policy implications.

\section{The Review Of The Selected Existing Literature}

The genesis of the collective bargaining could be traced to the desire of the workers to seek for what is commensurate to their input to their organisations in terms of time, talent, skills and potentials, as well as employer attempts to pay or reciprocate the workers efforts monetarily to such extent, which could not affect their profit margins (Fasan, 2011).

Trontman (2009), argues that the right to collective bargaining was born out of struggle and effective realization of the fundamental rights continues to be a challenge. It is a question of respect for fundamental principles at work and what arises from the basic respect, which is a balanced and fair outcome for all social and economic progress. Respect for their fundamental principles recognizes the mutually dependent nature of production-the fact that capital cannot create wealth by itself, it has to come from the energies of labour and those who own their own labour-the workers. A challenge remains as to how we are going to apply the fundamental principles, enshrined in convention No. 98, at the National level and progressively at the transnational and international level. However, collective bargaining constitutes an important means by which workers seeks to satisfy their economic and social interests. Successful collective bargaining is crucial to the attainment of industrial peace in Nigeria.

Nigeria Labour Law provides for automatic recognition of trade unions for collective bargaining purposes (Okene, 2007). This means that the employer must recognize registered trade unions in his establishment and bargaining with such unions in their bid to safeguard their economic interests in employment. The duty to recognise a trade union is conterminous with the duty to negotiate with it and conclude agreements. Thus, a refusal by an employer to recognise and bargaining with a union or adhere to the agreement arrived at could lead to strikes by workers to realize such improvements in working conditions.

According to Rioja (2009), collective bargaining is a very useful means to regulate workplace relations, also because it is used on a voluntary basis. It is something that needs to be linked at the place in which we work and can make a real contribution to national development, social harmony, rights, labour standards, and stable profitable and sustainable enterprises, which generate jobs and improve society. If used properly and in the context of macro industrial relations systems, collective bargaining has been a very useful tool in improving rights and protections, enterprises sustainability and facilitating workplace adaptation.

Okene (2007), argues that, by bargaining collectively with the management. Organized labour seeks to give effect to its legitimate expectations that wages and other conditions of work should be such as to guarantee a stable and adequate form of existence. To be compatible with the physical integrity and moral dignity of the individual, and those jobs should be reasonably secure. He continues that properly conducted, collective bargaining is the most effective means of giving workers the rights to representation in decisions affecting their working lives, rights which or should be the prerogative of every workers in a democratic society. 
Somavia (2009), expressly put that, the heart of the ILO's mandate; a source of its comparative advantage is collective bargaining. He continues that ILO's conventions No. 87 and 98 concretized the role of workplace democracy as a cornerstone of social peace and social justice, thus, promotion of universal ratification and application of this era. Moreso, ratification and application are not the same thing, but collective bargaining could only stable in the end when all parties are looking for fair solutions for all stakeholders rather than focusing on their differences. Thus, labour is not a commodity, that is, economic growth had to be reflected in social progress; those social progresses also support sustainable economic growth.

However, collective bargaining represents the backbone of the employer-employee relationship. It is widely accepted as the most important instrument for the determination of wages, employment conditions and the regulations of the employer-employee relations. In practice, collective bargaining is a process of obtaining concessions and reaching compromises on employment and working conditions. As a tool for the practice of Industrial Relations, collective bargaining may be interpreted in either a broad or a narrow sense. In its broad sense, it involves a process of interest accommodation through direct or indirect bipartite and tripartite dealings. By contract, in its narrow sense, collective bargaining is a process of negotiation between employers individually or as a group, and trade unions. The outcome of such negotiations is an obligatory document, a collective agreement that determines wages and other conditions of work. Importantly, the concept of collective bargaining has expanded considerably in recent years to encompass more than just the negotiation of collective agreements. It involves a continuous process of discussion, consultation and bargaining between employers and workers on a wide framework of economic policies globally.

\subsection{MULTINATIONAL ENTERPRISES AND TRADE UNIONS}

The impact of globalization is ever more evident to Industrial Relations in all countries and in all sectors. The increasing integration of national economies in a single global markets appearance of new world production systems are bringing about a convergence of national and international trade union agendas (Edwards and Kuruvilla, 2005). Trade unions face the double challenge of representing workers effectively in the rapidly changing conditions of the global economy, and of bringing about fundamental change in working of globalization so that it distributes it benefits more fairly and contributes to socially just and sustainable development.

A primary motivator for Nigerian and foreign-based unions to seek collective bargaining and to standardize labour conditions among the MNEs is to lessen competition from lower-wage areas and to protect their own standards-in other words, to take wages out of competition. To combat the power of the MNEs and to seek objectives that are mutually beneficial to the unions and their members, union leaders have tried two main approaches (Fajana, 2006).

1. Collective Bargaining

2. Legislative Enactment

Through collective bargaining, unions have attempted to either bargain directly with the MNEs or coordinate their bargaining activities with unions in other countries by sharing information and supporting one another's activities. However, the unions have become frustrated with attempts to achieve any degree of transnational bargaining, so they have concentrated on the adoption of codes of conduct to regulate MNEs behaviour. The International Labour Organization, a tripartite organization with governments, employers, and unions from 150 countries represented, established labour codes that state the MNEs should give priority to human rights, employment, safety, occupational development, social justice, and promotion and advancement of local nationals, and should provide stable employment and pay comparable wages (Fajana, 2006).

The Organization for Economic Cooperation and Development, an international organization headquartered in Paris, has also established "Guidelines for MNEs" concerning conduct in labour-management relations. These guidelines include certain rights: the rights to organize and bargain collectively, to have access to data for negotiations, to be trained as a member of the workforce, and to be given advance notice of changes in operations. Further, subsidiaries of MNEs are expected to observe employment standards comparable to those in the host countries; MNEs are expected not to threaten to shift productions to other countries to influence negotiations or to prevent unionization, and local management representative should be authorized to negotiate on behalf of the MNEs.

Unions, as well as some governments have asserted that collective bargaining on a national basis has considerable limitations in facing MNEs (Dowling and Welch, 2004). They continues that, this assertion is based on the belief that MNEs have adopted global strategies, so a union acting alone within one nation cannot effectively respond, likewise, some governments are uneasy about the fact that MNEs cannot easily be accountable to any one country's economic and social policies. Moreover, there has been persistent fear that if a 
union or government in one country acted without the support of unions or governments in other countries, it would risk transfer of operations by the MNEs to a more hospitable nation.

The creation of the European Union has led to a resurgence of interests in prospects of transnational collective bargaining. However, recent initiatives have taken the form of joint consultation and adherence to labour rights principles at a transnational level rather than true collective bargaining.

Dowling and Welch (2004), argues that, the aim of European trade unions is to achieve European-level collective bargaining. Despite the long recognized hurdles, there have been positive steps towards this end:

Firstly, the European Trade Union Confederation (ETUC) has become an effective voice for trade unions in the political arena and has the potential to become the spokesperson for European trade unions in collective bargaining.

Secondly, new agreements between trade unions in two countries have been signed. These agreements grant reciprocal memberships to members in both unions and provide for cooperation between these unions in exchanging information, developing closer coordinator with respect to European work councils, harmonization of pay demands and training.

The major important legal framework for holding business accountable is the systems of industrial relations under which collective bargaining takes place. Collective bargaining remains the most important private means to ensure that business activity has a positive social impact. Having good industrial relations is one of the most important social responsibilities of companies.

Collective bargaining serves as an essential idea with corporate governance: that a company does not consist of its management alone (Dowling and Welch, 2004). Even though, collective bargaining usually takes place without any government involvement, a legal framework, established by the government, is important in order to sort out who the parties are to engage in collective bargaining. This framework is also needed in order to ensure that the rights of workers to bargain collectively are respected by the employer. Without a supporting legal framework, collective bargaining may not realize its great potential to make business behave responsibly. Thus, in the absence of the framework, collective bargaining itself may not even be sustainable.

Globally, and on many levels, the nature of business relationships has changed. In many cases, these changing natures of business relationship bring enormous, challenges with it for trade unions. Bargaining Structures do needs to change along with the changing business structures, or they run the risk of getting outdated or invalid (Baldwin, 2006). One of the better-known examples is the fact that multinational enterprises are, in many sectors, getting more and more in to the business of outsourcing. In some extreme cases, large and well-known multinationals are in fact no longer producing anything. Products are brought from suppliers, with who they are relationship that is much looser than the companies had with their own subsidiaries before are. In some cases, the Multinational Enterprises itself turns out, in the end, to be not much more than the advertising leg of the production chain, responsible for promotion and selling of the product only, (Brown, 2001).

Under these circumstances, companies claim they have less influence over the production process. In fact, as they are in an often-unequal buyer-seller relationship, many of them are using this excuse not to have to interfere. The suppliers, often-small companies that operate through intermediaries, on the other hand, feel they have to compete in the race to the bottom, as they may otherwise be locked out of the benefits of globalization.

In dealing with Multinational Enterprises, it is important, but not always easy, to identify the real decisionmakers in the company. For example, on labour relations issues, the head office often says that local management makes all decisions. The local management team may say they have no control because decisions are being made elsewhere (Gollbach and Schulten, 2000). Although decision-making is, in fact, not the same within every company, one must assume that there is some role for the parent company. It may be necessary to established that the ultimate responsibility is at the headquarters level, especially if corporate behaviour violates fundamental workers' right. Another aspect of globalization is the increasing power of Multinational Enterprises. Multinational Enterprises have the power to disrupt collective bargaining agreements or bargaining structures. With the ever present threat of relation to countries with low wages, low standards and a low degree of organization. Multinational Enterprises are in a strong position to put pressure on trade unions and their workers, as well on their governments, to accept whatever they are proposing.

\subsection{THE THEORETICAL FRAMEWORK}

The successful operation of multinational enterprises is contingent upon the availability of technology, technological knowledge, capital and human resources. Without a high-developed pool of human resource (including managerial and technical talent), technology, technological knowledge and capital cannot be effectively and efficiently allocated or transferred from corporate headquarters to the scattered subsidiaries. Developing and managing this managerial and technical talent is the function of international human resource management (Munck, 2002). 
International human resource management has five main dimensions:

(a) The selection and recruitment of qualified individuals capable of furthering organisational goals.

(b) The training and development of personnel at all levels to maximize organizational performance.

(c) The assessment of employee performance to ensure that organizational goals are met.

(d) The retention of competent corporate personnel who can continue to facilitate the attainment of organizational goals

(e) The management of the interface between labour and management to ensure smooth organizational functioning (Munck, 2002).

Munck (2002), continues that an effective manager at home will also be an effective manager abroad. Moreover, many companies continue to focus primarily on the technical competence criterion for expatriate assignments. He identifies two reasons for this:

(a) Task requirements are usually more easily identifiable.

(b) Since technical competence usually prevents immediate failure on the job, particularly in high-pressure situations, the selectors play safe by placing a heavy emphasis on technical qualifications and little on the individual's ability to adapt to a foreign environment.

Both these assumptions are suspect, however, when one examines the rate of expatriate failure and the reasons for such failure.

In his classic work on theoretical perspectives of multinational enterprises, Jenkins (1987) identified two distinct groups of critics of multinational activities, namely, the global reach view and the neo-imperialist views. The former highlight the oligopolistic activities of MNEs. He argues that the intentions, motives and commitment of MNEs are to enhance their oligopolistic agendas rather than enhance capital flow to developing countries and dominance of multinationals emanates from competitive advantages they enjoy in developing countries. The neo-imperialist contends, that, state regulations also balanced oligopolistic powers of MNEs and they highlight the negative effects of creating a bourgeoisie dependency through MNEs activity, the interest of which tend to be the creation of luxuries for a minority elite class rather than ensuring the supply of basic needs for all.

Jenkins (1987) had earlier noted that, in conceptualizing what constitutes an Multinational Enterprises it is important to specify the level of overseas activities, either in terms of numbers of countries in which they operates or in terms of proportion of production, the value of assets and even the number of overseas employees. For example Agbesinyale (2003), argues that Harvard Business School's Multinational Enterprise Project defined a U.S firm as multinational only when it was listed in the Fortune 500 largest corporations and had subsidiaries in six or more foreign countries. Jenkins (1987) further opines that it is indeed up to any author to adopt which criterion serves his/her purpose.

In this, Jenkins (1987), definition of Multinational Enterprises, he excluded banks and services such as advertising and accounting, since to him these do not often relate to the expansion of industrial capital. Other writers have also tailored the definition of Multinational Enterprises according to various dimensions, as shown in the subsequent paragraph. Multinational Enterprises may be perceived in terms of ownership, management, strategy, and structural make up. Root (1994), suggest that, about ownership, a firm becomes multinational only when national of two or more countries owns the parent company. In such a case Shell and Unilever, controls by British and Dutch interests are multinationals. However, by this ownership criterion very few corporations are multinationals since nationals of a single nation own most Multinational Enterprises. Also with the management criterion, a firm qualifies as a multinational only when it has a nationality mix of headquarter managers. This is also very rare; as regards strategy. Root (1994), states that a global profit-maximizing firm is a multinational. Besides this multidimensional perspectives approach, Multinational Enterprises have also been categorized into horizontal vertical, and diversified Multinational Enterprises, depending on the way their production activities are configured (Dunning, 1993; Caves, 1996).

These categorizations are important since they tend to determine their behaviour and interaction with their subsidiaries, for instance the element of power is bound to be present in a vertically managed multinational, when it may not be an issue at all for a diversified multinationals configuration.

Neo-classical theorists articulate the merits of multinational operations in developing countries and this group of writers have been tagged optimists by Zhang et al (2006, p.31). The main thrust of their argument is that the market is an efficient tool for resource allocation and hence free trade that allows multinationals to operates anywhere in the world guarantees capital flow to the poor (Jenkins, 1987). They argues that first, this will in the very long run ensure global welfare, bridging the gap, between the rich and the poor by bringing into the host countries, capital, technologies, and skills that would otherwise not be available and creating jobs that would otherwise not be created (Richard et al, 2001; Hasnat, 2007). Second, Multinational Enterprises tend to 
bring best practices of workers right into host countries (Barlett and Ghoshal, 1989; OECD, 2002; Briscoe and Schulet, 2004; Harzing and Ruysseveldt, 2004). Third, Multinational Enterprises are likely to expand resources on employees training and development and pay higher wages to reduce labour turnover (Spar, 1999; Santoro, 2000; Moran, 2002; and Gallagher, 2005).

These notwithstanding there are several arguments against Multinational Enterprises in particular and neo-classical foundations in general. In his classic work on theoretical perspectives of multinational enterprises, Jenkens (1987) identified two distinct groups of critics of multinational activities, namely, the global reach view and the neo-imperialist views. Together these constitutes what Zhang, et al (2006, p.132) call the pessimists. The global reach views, though non-Marxist in its ideological foundations, conflicts with the neo-classical views. The former highlight the oligopolistic agendas rather than enhance capital flow to developing countries (Jenkins, 1987). According to Agbesinyale (2003,p.49), "The foundation of this view is reflected in industrial organizational theory and the U.S anti-trust tradition, which was first applied to the analysis of foreign direct investment by Hymer in 1960". The global reach theorists thus contend that the influence and dominance of multinational enterprises emanates from the competitive advantages they enjoy in developing countries. To the global reach theorist distortions in the markets are caused by the oligopolistic activities of Multinational Enterprises, rather than by external factors, as the neo-classic argued. One strong implication of this view is to advocate for state regulation that will balance oligopolistic powers Multinational Enterprises (Jenkins 1987). In addition, in opposition to neo-classical arguments of Multinational Enterprises are neo-imperialist views, which are Marxist - oriented and argues against Multinational Enterprises operations in the context of the world imperialism. They argue that as a consequence of the growing reserves of capital in capitalist countries, that need to seek investment outlets in developing countries is the main motive for direct investment and the desire to export capital to fill capital shortage gaps in developing countries (Jenkins, 1987). The unguarded quest for such investment outlets results in exploitation, by enhancing their competitiveness through cost- cutting centering on labour costs in host countries, as supported by anecdotal evidence (Standing 1997; Rodgers, 2002; Chain and Ross, 2003; Wood, 2006). Neo-imperialists further highlight the negative effect of creating a bourgeoisie dependency through Multinational Enterprise activity, the interest of which tend to be the creation of luxuries for a minority elite class rather than ensuring the supply of basic needs for all (Jenkins, 1987). As a typical Marxist view, the implication of the neo-imperialist views is that the unfortunate situation of developing states can be remedied through a social transformation.

Zhang et al (2006), also contributed to theoretical perspectives on the impact of multinational enterprises in developing countries by introducing the ambivalent view and the contingent view of MNEs. To them ambivalent perspective portrays MNEs as more constrained than the optimists and the pessimists suggest. The argument is that while powerful MNEs may seek to satisfy their competitive urge at all costs, they only succeed to a limited extent. In practice, they are often forced into accepting the legal regulations of the host country. According to Zhang et al (2006), the contingent perspective assumes that the impact of MNEs in developing countries is dependent on a number of factors and particular circumstances. These may includes factors like the types of multinationals, the nature of its operations (particularly with respect to value chains) the skills requirement for labour, the country or origin, and even the political and institutional environment in the host country. The ambivalent and contingent views of MNEs scholarship, especially since they can be used in appreciating the optimistic and pessimistic views.

\section{History Of Total Nigeria Plc}

The oil and gas industry is a pillar of the Nigerian economy and a major factor in its world standing. A member of OPEC, Nigeria is responsible for $8.24 \%$ of the organization's overall production. Total has been a partner from the very starts in the development of oil and gas in Nigeria, carrying both upstream and downstream activities.

Total Nigeria Plc was incorporated as a private company in 1956, became public in 1978, and is today quoted on the Nigeria Stock Exchange (NSE). Its principal activity is marketing of Petroleum Products and Liquefied Petroleum Gas. However, the company has diversified into the marketing of non-fuel products, through channels: the Network and General Trade. Since its first filling station at Herbert Macaulay street, Yaba, Lagos in 1956, the company has expanded its business through a network of over 500 retail outlets, corporate customers and organizations that are served through six (6) regions in Nigeria.

Total Nigeria Plc, a unique position in the Nigerian downstream oil and gas industry. A network of 500 retail outlets in six (6) regions: Lagos, Mid-Western, Eastern, Far North, North-Central and Western. Bulk storage facilities of Apapa, Ibafon, Kano, Kaduna and Bukuru Depots. 3 Lubricants Blending Plants at Koko in Delta State, at Kaduna in Kaduna State and Apapa in Lagos State. 10 Liquefied Petroleum Gas (LPG) bottling plants and a coastal storage in Apapa, Lagos. One of the two larger suppliers of JET A1 fuel to the Aviation industry in Nigeria at Lagos Airports (Domestic and International), Kano, Abuja and Port Harcourt Airports. 
TOTAL is the world's fourth-largest publicly-traded integrated oil and gas company, with operations in more than 130 countries spanning all aspects of the petroleum industry, including upstream operation (oil and gas exploration, development and production, LNG) and downstream operations (refining, marketing and the trading and shipping of crude oil and petroleum products).

TOTAL also produce base chemicals (petrochemicals and fertilizers) and specialty chemicals for the industrial consumer markets (rubber processing, resins, adhesives, and electroplating). In addition, TOTAL has interests in the coal mining and power generating sectors. TOTAL is also helping to secure the future of energy through its commitment to development renewable energies, such as wind, solar and photovoltaic power, and alternative fuels. With more than 95,000 employees worldwide, TOTAL reported sales of $€ 153.8$ billion in 2006.

\section{Data Analysis And Findings}

Demographic Profile of the Respondents, Level Of Awareness of Subjects, Compliance and Observance of Collective Bargaining.

This section contains the presentation and analysis of empirical data collected to enable us to establish the reality of collective bargaining agreement in Total Nigeria Plc. These will be complemented by information gathered from interviews with the Management Team, NUPENG and PENGASSAN officials of Total Nigeria Plc.

\subsection{DEMOGRAPHIC CHARACTERISTICS OF RESPONDENTS}

Out of 94 respondents $11(11.7 \%)$ were management team, 34 (36.2\%) were PENGASSAN staffers while the remaining $49(52.1 \%)$ are NUPENG Union workers.

Table 1: Distribution of the Respondents by Cadre

\begin{tabular}{|l|c|c|}
\hline & Frequency & Percentage \\
\hline Management Team & 11 & 11.7 \\
\hline PENGASSSAN & 34 & 36.2 \\
\hline NUPENG & 49 & 52.1 \\
\hline Total & 94 & 100 \\
\hline
\end{tabular}

Source: Authors computation

\section{Educational Qualification}

Out of 94 respondents, only 80 supplied information about their educational qualification. This represents $85.1 \%$ of all respondents. The number of respondents with a first degree or equivalent qualification 38 , representing $40.4 \%$ while $18(19.1 \%)$ a master's degree. There are 16 of the respondents with a diploma certificate while 8 only possesses the secondary school certificates.

It can be argued from these figures that the respondents for this study have a good educational background, which is a reflection of the educational requirements needed to work in the study covered. It also means that the respondents are likely to have good understanding of the issues addressed by the research.

Table 2: Distribution of the respondents by Educational Qualification

\begin{tabular}{|l|l|l|l|l|}
\hline S/No & Highest educational Qualification & Frequency & \% & Valid \% \\
\hline 1 & Secondary School & 08 & 8.5 & 10 \\
\hline 2 & Diploma/Certificate(OND, NCE etc.) & 16 & 17.1 & 20 \\
\hline 3 & First Degree or Equivalent (B.Sc./B.A./HND) & 38 & 40.4 & 47.5 \\
\hline 4 & Master's Degree & 18 & 19.1 & 22.5 \\
\hline 5 & Missing & 14 & 14.9 & \\
\hline & Total & $\mathbf{9 4}$ & $\mathbf{1 0 0 . 0}$ & $\mathbf{1 0 0 . 0}$ \\
\hline
\end{tabular}

\section{Source: Authors computation}

The length of service shows that the majority of the respondents, $48(51.1 \%)$ work less than four years, which probably explains the relatively low level of awareness in the contents of collective bargaining agreements. 
Only $74(78.7 \%)$ of all the respondents have worked for a period of less than 10 year. The full picture presents in table 3, below.

The reason for this was that some had stay for 10 years as casual/contract workers before confirmed to be permanent staff.

Table 3: Distribution of the Respondents by Length of Service

\begin{tabular}{|l|c|c|}
\hline \multicolumn{1}{|c|}{ Years } & Frequency & \% \\
\hline $0-4$ & 48 & 51.0 \\
\hline $5-9$ & 26 & 27.7 \\
\hline $10-14$ & 14 & 14.9 \\
\hline $15-19$ & 06 & 6.4 \\
\hline Total & 94 & 100 \\
\hline
\end{tabular}

Source: Authors computation

The distribution of respondents by sex sows that $79(84.1 \%)$ male and $15(16.0 \%)$ female. This show the male dominated the number of the respondents. The details are presented in the table 4.

Table 4: Distribution of the respondents by Sex

\begin{tabular}{|l|c|c|}
\hline & Frequency & \% \\
\hline MALE & 79 & 84.1 \\
\hline FEMALE & 15 & 16.0 \\
\hline Total & 94 & 100 \\
\hline
\end{tabular}

Source: Authors computation

\section{Age Distribution}

In terms of age, the majority of our respondents fall below the age of 50. This suggests a relatively young group who are likely to be concerned about the compliance of collective bargaining agreement and entitlement at work. The complete information presented below in table 5 .

Table 5: Distribution of the Respondents by Age

\begin{tabular}{|l|c|c|}
\hline \multicolumn{1}{|c|}{ AGE } & Frequency & \% \\
\hline $20-29$ & 39 & 41.5 \\
\hline $30-39$ & 28 & 29.8 \\
\hline $40-49$ & 18 & 19.1 \\
\hline $50 \&$ above & 09 & 9.6 \\
\hline Total & 100 & 100.0 \\
\hline
\end{tabular}

Source: Authors computation

\subsection{AWARENESS OF THE SUBJECTS OF COLLECTIVE BARGAINING AGREEMENTS AND WORKERS RIGHTS}

In ascertaining the extent to which respondents know the contents in the collective bargaining agreements, the first question they were asked is if they are aware of the contents in the collective bargaining agreement. In response to this, out of 94 respondents 90 , representing 95.7\%, claim to be aware while 4 (4.3\%) answered in the negative. This pattern of response suggests a high level of awareness. The responses are presented in table 6 below.

Table 6: Awareness of the Subjects of Collective Bargaining

\begin{tabular}{|l|c|c|}
\hline & Frequency & \% \\
\hline YES & 90 & 95.7 \\
\hline NO & 4 & 4.3 \\
\hline Total & 94 & 100 \\
\hline
\end{tabular}

Source: Authors computation 


\section{Questions on identified rights and mandatory subject of collective bargaining}

As a follow-up to the above questions. Respondents were asked to mention what they consider as mandatory subjects of collective bargaining and workers rights, to determine how conversant they are with the regime of collective bargaining and workers rights.

In all, 11 and 35 categories of subjects of collective bargaining and workers rights were identified. With a total of 480 and 2106 responses, (respondents were allowed multiple responses). The rights with highest frequency are economic (incorporating the issues of salary and welfare) at 91 responses which is $19.0 \%$ of the total: the rights to associate ranks second with $78(16.3 \%)$ responses, followed by right to participate in management/freedom of expression at work with $56(11.7 \%)$ responses. The right to annual leave comes next with $70(14.6 \%)$ responses while the right to life/personal security/ safety has a frequency of $51(10.6 \%)$. It is interesting to note that the right to job security was mentioned only eight times while no one mentioned maternity rights, not even the female respondents. This pattern of responses does not suggest a deep appreciation of what is involved in the advocacy for workers' rights. For example, the right to associate is regarded as central to assessing other rights, but the respondents do not accord it much importance. The same thing is true of the right to participate in management/freedom of expression which approximates to the rights to organize and collective bargaining (a fundamental rights declared by the ILO) and may influence positively on economic benefits at work. The responses (as individually identified are indicated in the table 7 and 8 below).

Table 7: identified Rights

\begin{tabular}{|l|l|l|l|}
\hline S/No & \multicolumn{1}{|c|}{ Contents Identified } & Responses & $\%$ \\
\hline 1 & Economic (salary/welfare) & 91 & $\mathbf{1 9 . 0}$ \\
\hline 2 & Social rights & 13 & 2.7 \\
\hline 3 & Annual leave & 56 & 11.7 \\
\hline 4 & Participation in management/freedom of expression & 70 & 14.6 \\
\hline 5 & Right to promotion & 18 & 3.8 \\
\hline 6 & Right to associate & 78 & 16.3 \\
\hline 7 & Political right & 37 & 7.7 \\
\hline 8 & Right to further education & 43 & 9.0 \\
\hline 9 & Right to private life & 12 & 2.5 \\
\hline 10 & Job security & 11 & 2.3 \\
\hline 11 & Life and personal security and safety & 51 & 10.6 \\
\hline & Total & $\mathbf{4 8 0}$ & $\mathbf{1 0 0}$ \\
\hline
\end{tabular}

Source: Authors computation

Table 8: Mandatory Subject of Collective Bargaining

\begin{tabular}{|l|l|c|c|}
\hline S/No & & Frequency & \% \\
\hline 1 & Hourly pay or incentive (piece) rate of pay & 90 & 43 \\
\hline 2 & bonus pay & 93 & 4.4 \\
\hline 3 & Profit sharing plan & 89 & 4.2 \\
\hline 4 & Employee stock ownership plan & 62 & 2.9 \\
\hline 5 & Lump-sum pay & 92 & 4.4 \\
\hline 6 & Two-tier wage plan & 15 & 0.7 \\
\hline 7 & Shift differential pay & 43 & 2.0 \\
\hline 8 & Overtime & 71 & 3.4 \\
\hline 9 & Vacation pay & 16 & 0.8 \\
\hline 10 & Employee discounts on company's products or service & 78 & 3.7 \\
\hline 11 & Price of meal provided by company & 91 & 4.3 \\
\hline 12 & Child-care assistance plan & 64 & 3.0 \\
\hline 13 & Life insurance & 94 & 4.5 \\
\hline 14 & Leave of absence & 41 & 1.9 \\
\hline 15 & Health and accident insurance & 82 & 3.9 \\
\hline
\end{tabular}


The Current Status of Collective Bargaining and Its Implications on Bottom-Line Performance in

\begin{tabular}{|l|l|c|c|}
\hline 16 & Hours of work & 72 & 3.4 \\
\hline 17 & Pension plan & 89 & 4.2 \\
\hline 18 & Job duties and qualifications & 77 & 3.7 \\
\hline 19 & Job transfer rights and procedures & 68 & 3.2 \\
\hline 20 & Job promotion criteria and procedures & 70 & 3.3 \\
\hline 21 & Lay off and recall procedures & 66 & 3.1 \\
\hline 22 & Seniority rights & 46 & 3.2 \\
\hline 23 & Length of job probation period & 57 & 2.7 \\
\hline 24 & Grievance-arbitration procedures & 69 & 3.3 \\
\hline 25 & Management rights & 17 & 0.8 \\
\hline 26 & Sub contracting of bargaining unit work & 53 & 2.5 \\
\hline 27 & Joint union-management cooperation plan & 42 & 1.9 \\
\hline 28 & Employee testing procedures (e.g. during test) & 1 & 0.5 \\
\hline 29 & Performance evaluation methods and procedures & 62 & 2.9 \\
\hline 30 & Safety and health standards and procedures & 86 & 4.1 \\
\hline 31 & Successor ship clause & 2 & 0.9 \\
\hline 32 & No strike or lock out clause & 40 & 1.9 \\
\hline 33 & Retirement age & 93 & 4.4 \\
\hline 34 & Duration of agreements & 28 & 1.3 \\
\hline 35 & Employee physical examination & 47 & 2.2 \\
\hline & Total & $\mathbf{2 1 0 6}$ & \\
\hline
\end{tabular}

\section{Source: Authors computation}

\section{Sources of Identified Subject of Collective Bargaining and Workers' Rights}

Respondents were asked how they learnt of their rights and mandatory subject of collective bargaining. The recurring source is the companies/employee's handbook and previous work experience while the second mostly source previous collective bargaining and educational background such as the formal school systems, seminars and the mass media. These are not sources that are likely to lay much emphasis on the far-reaching subject of collective bargaining and rights of workers. Management with little or no inputs from employees usually draws up the employees' handbook, containing duties and rights of employee as well as the obligations of employers to workers. In the same vein, the formal school system, most seminar programmes and the mass media have not been proponents of social change. The out going trade union executive should sensitize the incoming about the subject of collective bargaining and workers rights as soon as they are elected. Just as the management gives the "Employees' Handbook" to the new worker, the union should give him a union manual detailing subject of collective bargaining and workers' rights. The responses are as indicated in Table 9 below.

Table 9

\begin{tabular}{|l|l|c|c|}
\hline S/No & & Frequency & \% \\
\hline 1 & Company's Handbook & 25 & 26.6 \\
\hline 2 & Union & 09 & 9.6 \\
\hline 3 & Previous collective bargaining agreements & 18 & 19.1 \\
\hline 4 & Previous work experience & 26 & 27.7 \\
\hline 5 & At school/seminars/media/other workers. & 16 & 17.0 \\
\hline & Total & $\mathbf{9 4}$ & $\mathbf{1 0 0}$ \\
\hline
\end{tabular}

\section{Source: Authors computation}

\section{Workers rights and the subjects of collective bargaining deserved by workers}

As follow-up and to be sure that respondents are at home with the issues at stake, they were asked to mention specific subjects of collective bargaining and rights they think workers deserved. 
Table 10

\begin{tabular}{|l|l|c|c|}
\hline S/No & \multicolumn{1}{|c|}{ Responses } & Frequency & \% \\
\hline 1 & Work under conducive Atmosphere & 08 & 8.5 \\
\hline 2 & Association & 12 & 12.7 \\
\hline 3 & Participation in Management/ Freedom of Expression & 10 & 10.6 \\
\hline 4 & Promotion & 11 & 11.7 \\
\hline 5 & Annual leave & 06 & 6.4 \\
\hline 6 & Economic (regular salary/welfare) & 16 & 17.1 \\
\hline 7 & Further Education & 06 & 6.4 \\
\hline 8 & Political Participation & 08 & 8.5 \\
\hline 9 & Pension & 02 & 2.1 \\
\hline 10 & Life/personal/security/safety & 14 & 14.9 \\
\hline 11 & Religion & 01 & 1.1 \\
\hline & Total & $\mathbf{9 4}$ & $\mathbf{1 0 0}$ \\
\hline
\end{tabular}

\section{Source: Authors computation}

\subsection{OBSERVANCE AND, COMPLIANCE WITH, THE SUBJECTS IN COLLECTIVE BARGAINING AND WORKERS' RIGHTS.}

\section{The Extent to which Subject in Collective Bargaining is Observed/Complied.}

As shown in table 11 above, the highest level of dissatisfaction, $48.9 \%$ of respondents. This is perhaps and indication of the perception of the question of observance of, and compliance with, the subjects in collective bargaining and workers' rights.

Table 11

\begin{tabular}{|l|c|c|}
\hline & Frequency & \% \\
\hline Fully Observed & 21 & 11.7 \\
\hline Reasonable & 35 & 37.3 \\
\hline Not Satisfied & 46 & 48.9 \\
\hline Can't say & 2 & 2.1 \\
\hline Total & $\mathbf{9 4}$ & $\mathbf{1 0 0}$ \\
\hline
\end{tabular}

Source: Authors computation

\section{Examples of Non-Observance/ Compliance}

Respondents were asked to mention examples or instances of non-observance of the subjects of collective bargaining and workers' rights. As indicated in the table 12 below, longtime stayed as casual/contracts staff before confirmation as permanent staff is most frequently mentioned with 26 responses, followed by forced resignation 14 responses while deny study leave and threat from employers were 12 responses respectively. Lack of promotion and arbitrariness on the part of management were 9 and 8 responses respectively. Non- unionization mentioned 1 time and late lunch came up for mention 5 times.

Table 12

\begin{tabular}{|l|l|c|c|}
\hline S/No & & Frequency & \% \\
\hline 1 & Forced resignation & 13 & 13.8 \\
\hline 2 & Late working hours & 4 & 4.3 \\
\hline 3 & Lack of promotion & 9 & 9.6 \\
\hline 4 & Late lunch & 5 & 5.3 \\
\hline 5 & Sexual harassment & 2 & 2.1 \\
\hline 6 & Later payment of salary and allowances & 2 & 2.1 \\
\hline 7 & Arbitrary management & 8 & 8.5 \\
\hline 8 & Non-unionization & 1 & 1.1 \\
\hline
\end{tabular}


The Current Status of Collective Bargaining and Its Implications on Bottom-Line Performance in

\begin{tabular}{|l|l|c|c|}
\hline 9 & Deny study leave & 12 & 12.8 \\
\hline 10 & Threat from employees & 12 & 12.8 \\
\hline 11 & $\begin{array}{l}\text { Longtime as casual/contracts staff before confirmation of } \\
\text { appointment }\end{array}$ & 26 & 27.7 \\
\hline & Total & $\mathbf{9 4}$ & $\mathbf{1 0 0}$ \\
\hline
\end{tabular}

Source: Authors computation

\section{Problems Encountered at work}

Closely related to the below, respondents were asked to mention the problems encountered at work as such may be indicative of rights abuses and non-compliance with subject in collective bargaining. This enable us to cross check their responses to the earlier questions on non-observance of, and compliance with, subjects collective bargaining as well as a test of their understanding of rights issues at work. The responses are listed in table 13 below, the issues listed include; too much work, sexual harassment, abuse of rights, late payments of salary, late closing, job insecurity and humiliation/intimidation. The responses are similar to those in table 12 above and they confirmed non-compliance of subjects in collective bargaining.

Table 13

\begin{tabular}{|l|l|c|c|}
\hline S/No & \multicolumn{1}{|c|}{ Responses } & Frequency & \% \\
\hline 1 & Too much work & 6 & 6.4 \\
\hline 2 & Sexual harassment & 1 & 1.1 \\
\hline 3 & Abuse of rights & 12 & 12.8 \\
\hline 4 & Distrust among workers & 9 & 9.6 \\
\hline 5 & Late payment of salary & 2 & 2.1 \\
\hline 6 & Transportation & 2 & 2.1 \\
\hline 7 & Late lunch & 4 & 4.3 \\
\hline 8 & Late closing & 2 & 2.1 \\
\hline 9 & Non-observance of public holidays & 1 & 1.1 \\
\hline 10 & Poor corporate communication & 12 & 12.8 \\
\hline 11 & Job Insecurity & 9 & 9.6 \\
\hline 12 & Humiliation/Threat/Intimidation & 26 & 27.7 \\
\hline 13 & Delay in approval of annul leave & 8 & 8.5 \\
\hline & Total & & \\
\hline
\end{tabular}

\section{Source: Authors computation}

\section{Response to Non-Observance/Compliance}

When problems are encountered at work, it is not out of place to expect those involved to respond one way or the other. The responses of our respondents to such developments are indicated in table 14 below. All the respondents' responds to this question, 38 complained to higher authorities. In addition, 38 complained indifferent while 6 reported to the union. The remaining 12 respondents called for a meeting to address the situation. The 38 respondents remained indifferent could be either a case of helplessness resulting from a lack of confidence in the ability of management to act in their (workers) interest or ignorance of what to do. This percentage is probably borne out of the realization that complaining to the same people responsible for their plight may amount to an exercise in futility.

Table 14

\begin{tabular}{|l|l|c|c|}
\hline S/No & & Frequency & \% \\
\hline 1 & Complained & 38 & 40.4 \\
\hline 2 & Called meeting & 12 & 12.8 \\
\hline 3 & Indifference & 38 & 40.4 \\
\hline 4 & Reported to Union & 6 & 6.4 \\
\hline & Total & $\mathbf{9 4}$ & $\mathbf{1 0 0 . 0}$ \\
\hline
\end{tabular}

Source: Authors computation 


\section{Steps towards resolution on non-compliance of subjects in collective bargaining and workers' rights.}

It was necessary to know what particular steps respondents took over non-compliance of subjects of collective bargaining and workers' rights. While 8 out of 94 respondents called for union meeting, 32 opted for patience and understanding, 44 opted for dialogue with management. Only 6 respondents decided to seek redress. The remaining 4 respondents who took apparent step can be taken along with those who decided to be patient and bear with the situation (understanding). It then means that 36 out of 94 respondents $(38.3 \%)$ were simply not bothered or perhaps hopeless about the non-observance of the subjects in the collective bargaining and workers' rights. This pattern of response reinforces our earlier observation that workers may not have confidence in their employers being fair to them. As we shall show shortly, quite a number of the respondents are aware of awareness for seeking redress (see table 16 below).

Table 15:

\begin{tabular}{|l|l|c|c|}
\hline S/No & \multicolumn{1}{|c|}{ Steps Towards Resolution } & Frequency & \% \\
\hline & Union meeting & 8 & 8.5 \\
\hline & Patience and understanding & 32 & 34.0 \\
\hline & Dialogue with management & 44 & 46.8 \\
\hline & Call for redress & 6 & 6.4 \\
\hline & None & 4 & 4.3 \\
\hline & Total & $\mathbf{9 4}$ & $\mathbf{1 0 0 . 0}$ \\
\hline
\end{tabular}

Source: Authors computation

\section{Awareness of Avenue to seek redress}

Respondents were also asked if they are aware of avenues of seeking redress in case of nonobservance/compliance of subjects of collective bargaining and workers' rights. A total of 72 respondents representing $76.6 \%$ of the entire sample size are aware of avenues for seeking redress while 32 answered in negative (see table 17 below).

Table 16

\begin{tabular}{|l|c|c|}
\hline & Frequency & \% \\
\hline MALE & 72 & 76.6 \\
\hline FEMALE & 22 & 23.4 \\
\hline Total & 94 & 100 \\
\hline
\end{tabular}

\section{Source: Authors computation}

\section{Identified Avenues for Seeking Redress}

The specific avenues listed are shown in table 17 below. The responses here are quite revealing. The majority of those who responded to this question, 52 out of $94(55.3 \%)$ pick the union on the avenue for seeking redress. Only $16(17.0 \%)$ mention court and other state agencies as avenues for redress while the remaining 22 $(23.4 \%)$ identify management and $4(4.3 \%)$ did not respond to the question. This pattern of response is a further confirmation of the lack of confidence in the ability of management to protect the interests/rights of workers.

\section{Table 17}

\begin{tabular}{|l|c|c|}
\hline & Frequency & \% \\
\hline Management & 22 & 23.4 \\
\hline Union & 52 & 55.3 \\
\hline Court/State Agencies & 16 & 17.0 \\
\hline Can't say & 4 & 4.3 \\
\hline Total & 94 & 100.0 \\
\hline
\end{tabular}

Source: Authors computation

\section{Assessment of Management Response}

Respondents were also asked to assess the response of management to the problems they encounter at work. Only $13(13.8 \%)$ of 94 respondents claimed to be satisfied with the response of management. The remaining $81(86.2 \%)$ were not satisfied (see table 18 for details). 
Table 18

\begin{tabular}{|l|c|c|}
\hline & Frequency & \% \\
\hline Adequate & 13 & 13.8 \\
\hline Not Adequate & 81 & 86.2 \\
\hline Total & $\mathbf{9 4}$ & $\mathbf{1 0 0}$ \\
\hline
\end{tabular}

Source: Authors computation

\section{Further Steps taken to Seek Redress}

If respondents were not satisfied by management's response to their complaints or grievances, we sought to know what further steps they took to seek redress. Out of the 81 that felt management's response was not adequate, $82(87.2 \%)$ of the sample, size took further steps of either complaining to the union or making suggestions to the management. While $12(12.8 \%)$ do not make any comments. These are reflected in table 19 below.

Table 19

\begin{tabular}{|l|c|c|}
\hline & Frequency & \% \\
\hline Complained to Union & 64 & 68.1 \\
\hline Made Suggestions & 18 & 19.1 \\
\hline None & 12 & 12.8 \\
\hline Total & $\mathbf{9 4}$ & $\mathbf{1 0 0 . 0}$ \\
\hline
\end{tabular}

Source: Authors computation

\section{Can union be of helped in seeking redress?}

Specifically, respondents were asked if the union could be useful in seeking redress. $73(77.7 \%)$ of the entire of 94 respondents believe the union can be helpful (either fully or partially) (Table 20). Again, this is a demonstration of the respondents' confidence in the trade union organization. Apart from seeking redress on behalf of workers, other ways the respondents think that the union can be helpful are; through negotiations, strike actions, enlightenment, schemes (see Table 21 below)

Table 20: Can Union be helpful in seeking redress?

\begin{tabular}{|l|c|c|}
\hline & Frequency & \% \\
\hline Yes & 61 & 64.9 \\
\hline Partially & 12 & 12.8 \\
\hline No & 21 & 22.3 \\
\hline Total & $\mathbf{9 4}$ & $\mathbf{1 0 0 . 0}$ \\
\hline
\end{tabular}

Source: Authors computation

Table 21: How union can be helpful in seeking redress?

\begin{tabular}{|l|l|l|l|}
\hline S/No & How Union can be helpful & Frequency & \% \\
\hline 1 & Through Negotiation & $\mathbf{1 8}$ & $\mathbf{1 9 . 1}$ \\
\hline 2 & Through Strike & $\mathbf{3 2}$ & $\mathbf{3 4 . 0}$ \\
\hline 3 & $\begin{array}{l}\text { Protection of Collective Bargaining agreement } \\
\text { through arbitration panel }\end{array}$ & $\mathbf{1 6}$ & $\mathbf{1 7 . 1}$ \\
\hline 4 & $\begin{array}{l}\text { Protection of collective Bargaining agreement } \\
\text { through enlightenment }\end{array}$ & $\mathbf{2 8}$ & $\mathbf{2 9 . 8}$ \\
\hline Total & $\mathbf{9 4}$ & $\mathbf{1 0 0 . 0}$ \\
\hline
\end{tabular}

Source: Authors computation

\section{Feelings about Non-Unionization}

If respondents believe workers should unionize, how do they feel in the absence of unions in their organization? We asked them this question as well as, what could be the situation without the unions in their organization? Broadly, majority of the respondents $64(68.1 \%)$ argues that the situation would be worsen, they insists that it would be degrading, exploitative, it would put them at a disadvantage and embarrassing not to have a union in place of work (All these responses reflected in the table 22). While $20(21.3 \%)$ of the sample 
size were indifference and do not care. This means that the unions need to work more on raising workers' consciousness to develop more interest and enthusiasm in trade unionism.

In addition, the unions need to adopt a more inclusive approach in their activities such that the interests and concerns of all members can be factored in.

Table 22: Feelings about Non-Unionization

\begin{tabular}{|l|l|l|l|}
\hline S/No & & Frequency & \% \\
\hline 1 & Degrading & $\mathbf{2 9}$ & $\mathbf{3 0 . 9}$ \\
\hline 2 & Exploitative & $\mathbf{1 2}$ & $\mathbf{1 2 . 8}$ \\
\hline 3 & Disadvantage & $\mathbf{1 0}$ & $\mathbf{1 0 . 6}$ \\
\hline 4 & Embarrassed/Depressed & $\mathbf{1 3}$ & $\mathbf{1 3 . 8}$ \\
\hline 5 & Don't care & $\mathbf{1 8}$ & $\mathbf{1 9 . 1}$ \\
\hline 6 & Indifference & $\mathbf{1 2}$ & $\mathbf{1 2 . 8}$ \\
\hline & Total & $\mathbf{9 4}$ & $\mathbf{1 0 0 . 0}$ \\
\hline
\end{tabular}

Source: Authors computation

\subsection{WHAT CAN BE DONE TO ENSURE COMPLIANCE WITH THE SUBJECTS IN COLLECTIVE BARGAINING AGREEMENT}

The fourth major issue examined in this research is what can be done to ensure compliance with, and enforcement of subjects in collective bargaining and workers' rights. In this regard, the following questions were posed. The first question is; what can be done to ensure enforcement of workers' rights and compliance with subjects on collective bargaining. Responses range from encourage unionism, union empowerment, continuous dialogue (presumably with management), training and educating work place actors, protests and sanctions, end to intimidation of workers, while allowing freedom of expression. Five of the suggestions related directly to the union with a combined frequency of $83(88.3 \%)$ out of 94 respondents. These are suggestions that trade unionism should enforced, union should empowered, and imposition of sanctions/protests. These are in items $1,2,3,4$ and 5 on table 23 below

Table 23: What can be done to Ensure Compliance?

\begin{tabular}{|l|l|c|c|}
\hline S/No & & Frequency & \% \\
\hline 1 & Encourage/insist on unionism, & 22 & 23.4 \\
\hline 2 & Union empowerment & 28 & 29.8 \\
\hline 3 & Continuous dialogue & 6 & 6.4 \\
\hline 4 & Training/Education & 18 & 19.1 \\
\hline 5 & Through Protests/Sanctions & 9 & 9.6 \\
\hline 6 & Constant changes of bosses (Management) & 5 & 5.3 \\
\hline 7 & Stop intimidation/allow freedom of expression & 5 & 5.3 \\
\hline 8 & Don't know & 1 & 1.1 \\
\hline & Total & $\mathbf{9 4}$ & $\mathbf{1 0 0 . 0}$ \\
\hline
\end{tabular}

\section{Source: Authors computation}

\section{Can union help in securing workers' rights and compliance with subjects on collective bargaining?}

The next question specifically asked respondents if the union could help in securing workers' rights and compliance with subjects in collective bargaining. Out of a total of the sample size, $86(91.5 \%)$ respondents answered in the affirmative. This contrasts with the 8 who do not think the union can help in this regard (see table 24 below). This is further affirmation of respondents' belief in trade unions.

Table 24

\begin{tabular}{|l|l|c|c|}
\hline S/No & & Frequency & \% \\
\hline & Yes & 86 & 91.5 \\
\hline & No & 5 & 5.3 \\
\hline & No Response & 3 & 3.2 \\
\hline & Total & $\mathbf{9 4}$ & $\mathbf{1 0 0 . 0}$ \\
\hline
\end{tabular}

Source: Authors computation 
Other ways in which union can be helpful?

Finally, respondents were asked to mention other ways in which the union can be helpful. Their answers are listed in table 25 below.

The union should negotiate on behalf of the workers not to get their ways at the detriments of the workers' and social action should be encouraged has the highest frequency of 44 (46.8\%).

While ensuring enforcement and protection of human rights, checking excess of the management 29 $(30.8 \%)$ and third highest frequency of $21(23.2 \%)$ suggests that union should act as link between workers and management and union should secured addition more income to defend themselves in terms of litigation.

More importantly, from the data presented in the preceding paragraphs, the reality is not too encouraging. This poses many challenges of those who are saddled with the responsibility of ensuring that subjects in collective bargaining and workers' rights are respected.

Table 25

\begin{tabular}{|l|l|c|c|}
\hline S/No & & Frequency & \% \\
\hline & Ensure enforcement/protection & 13 & 13.8 \\
\hline & Encourage social action & 18 & 19.1 \\
\hline & Negotiate on behalf of workers & 26 & 27.7 \\
\hline & Act as link between workers and management & 13 & 13.8 \\
\hline & Secure additional/More income & 8 & 8.5 \\
\hline & Check excesses of management & 16 & 17.1 \\
\hline & & $\mathbf{9 4}$ & $\mathbf{1 0 0 . 0}$ \\
\hline
\end{tabular}

Source: Authors computation

\subsection{TESTING OF HYPOTHESES I, II, III}

\section{Testing of Hypothesis I}

$\mathrm{H}_{0}$ : There is no significant relationship between awareness of workers and contents on collective bargaining agreements.

Using questions $1,6,9$ and 18 relevant to proffer insight into this hypothetical statement after analyses thus;

\begin{tabular}{|l|l|l|l|l|l|l|}
\hline Question & & & & & & Total \\
\hline 1 & $11(\mathrm{a})$ & $34(\mathrm{~b})$ & $49(\mathrm{c})$ & & & 94 \\
\hline 6 & $90(\mathrm{~d})$ & $4(\mathrm{e})$ & & & & 94 \\
\hline 9 & $25(\mathrm{f})$ & $9(\mathrm{~g})$ & $18(\mathrm{~h})$ & $26(\mathrm{i})$ & $16(\mathrm{j})$ & 94 \\
\hline 18 & $13(\mathrm{k})$ & $81(\mathrm{l})$ & & & & 94 \\
\hline Total & 139 & 128 & 67 & 26 & 16 & 376 \\
\hline
\end{tabular}

From the questionnaire

\begin{tabular}{|l|l|l|l|l|l|}
\hline SN & $\mathbf{O}$ & $\mathbf{E}$ & $\mathbf{( O - E )}$ & $\mathbf{O}-\mathbf{E} / \mathbf{E}$ & $\mathbf{E}(\mathbf{O}-\mathbf{E} / \mathbf{E}) \mathbf{2}$ \\
\hline A & 11 & 34.75 & -23.75 & -0.6835 & 0.4672 \\
\hline B & 34 & 32 & 2 & 0.0625 & 0.0039 \\
\hline C & 49 & 16.75 & 32.25 & 1.9254 & 3.7072 \\
\hline D & 90 & 34.75 & 55.25 & 1.59 & 2.5281 \\
\hline E & 4 & 32 & -28 & -0.875 & 0.7656 \\
\hline F & 25 & 34.75 & -9.75 & -0.2806 & 0.0787 \\
\hline G & 9 & 32 & -23 & -0.7188 & 0.5167 \\
\hline H & 18 & 16.75 & 1.25 & 0.0746 & 0.0056 \\
\hline I & 26 & 6.5 & 19.5 & & 9 \\
\hline J & 16 & 4.0 & 12 & 3 & 9 \\
\hline K & 13 & 34.75 & -21.75 & -0.6259 & 0.3918 \\
\hline L & 81 & 32 & 49 & 1.5313 & 2.3449 \\
\hline Chi Square & & & & & 28.8097 \\
\hline
\end{tabular}




\section{Determination of critical value:}

Degree of freedom $(\mathrm{df})=(\mathrm{n}-1)(\mathrm{r}-1)$

Where:

$$
\begin{aligned}
& \mathrm{n}=\text { column } \\
& \mathrm{r}=\text { Column }
\end{aligned}
$$

Degree of freedom $(\mathrm{df})=(4-1)(5-1)=(3)(4)=12$

That is 16 at 0.05 , then Chi Square Table $\left(\mathrm{X}^{2} \mathrm{Tab}\right)=21.026$

While Chi Square Calculated $\left(X^{2}\right.$ cal $)=28.8097$

\section{Decision Rule}

If $\mathrm{X}^{2}$ tab is greater than $(>) \mathrm{X}^{2}$ cal at 0.05 accept Null $\left(\mathrm{H}_{\mathrm{O}}\right)$

Otherwise, reject Null $\left(\mathrm{H}_{\mathrm{O}}\right)$

From the above computation, Chi Square Table $\left(X^{2}\right.$ Tab) at 21.026 is less than Chi Square calculated $\left(X^{2}\right.$ cal $)$ at 28.8097 reject null hypothesis. Therefore, there is significant relationship between awareness of workers and contents on collective bargaining agreements.

\section{Testing of Hypothesis II}

$\mathrm{H}_{\mathrm{O}}$ : There is no significant relationship between observance and compliance with the subjects in collective bargaining

For the analyses, questions $10,11,12,13$ and 15 relevant to the hypothetical statement after analyses was used thus;

\begin{tabular}{|l|l|l|l|l|l|}
\hline Question & & & & & Total \\
\hline 11 & $21(\mathrm{a})$ & $35(\mathrm{~b})$ & $46(\mathrm{c})$ & $2(\mathrm{~d})$ & 104 \\
\hline 16 & $72(\mathrm{e})$ & $22(\mathrm{f})$ & & & 94 \\
\hline 18 & $13(\mathrm{~g})$ & $81(\mathrm{~h})$ & & & 94 \\
\hline 20 & $61(\mathrm{i})$ & $12(\mathrm{j})$ & $21(\mathrm{k})$ & & 94 \\
\hline Total & 167 & 150 & 67 & 2 & 386 \\
\hline
\end{tabular}

From the questionnaire

\begin{tabular}{|l|l|l|l|l|l|}
\hline SN & $\mathbf{O}$ & $\mathbf{E}$ & $\mathbf{( O - E )}$ & $\mathbf{O - E} / \mathbf{E}$ & $\mathbf{E}(\mathbf{O}-\mathbf{E} / \mathbf{E})^{\mathbf{2}}$ \\
\hline A & 21 & 44.99 & -23.99 & -0.5332 & 0.2843 \\
\hline B & 35 & 40.41 & -5.41 & -0.1339 & 0.0179 \\
\hline C & 45 & 18.05 & 26.95 & 1.4931 & 2.2293 \\
\hline D & 2 & 0.54 & 1.46 & 2.7037 & 7.31 \\
\hline E & 72 & 40.67 & 31.33 & 0.7703 & 0.5934 \\
\hline F & 22 & 36.53 & -14.53 & -0.3978 & 0.1582 \\
\hline G & 13 & 40.67 & -27.67 & -0.6804 & 0.4629 \\
\hline H & 81 & 36.53 & 44.47 & 1.2174 & 1.4821 \\
\hline I & 61 & 40.67 & 20.33 & 0.4999 & 0.2499 \\
\hline J & 12 & 36.53 & -24.53 & -0.6715 & 0.4509 \\
\hline K & 21 & 16.32 & 4.68 & 0.2868 & 0.0823 \\
\hline Chi Square & & & & & 13.3212 \\
\hline
\end{tabular}

\section{Determination of critical value:}

Degree of freedom $(\mathrm{df})=(\mathrm{n}-1)(\mathrm{r}-1)$

Where:

$$
\begin{aligned}
& \mathrm{n}=\text { column } \\
& \mathrm{r}=\text { Column }
\end{aligned}
$$

Degree of freedom $(\mathrm{df})=(4-1)(4-1)=(3)(3)=9$

That is 16 at 0.05 , then Chi Square Table $\left(\mathrm{X}^{2} \mathrm{Tab}\right)=16.919$

While Chi Square Calculated $\left(\mathrm{X}^{2}\right.$ cal $)=13.321$

\section{Decision Rule}

If $\mathrm{X}^{2}$ tab is greater than (>) $\mathrm{X}^{2}$ cal at 0.05 , accept Null $\left(\mathrm{H}_{\mathrm{O}}\right)$ 
Otherwise, reject Null $\left(\mathrm{H}_{\mathrm{O}}\right)$

From the above computation, Chi Square Table $\left(\mathrm{X}^{2} \mathrm{Tab}\right)$ at 16.919 is greater than Chi Square Calculated $\left(\mathrm{X}^{2}\right.$ cal $)$ at 13.3212 accept null hypothesis. Therefore, there is no significant relationship between observance and compliance with the subjects in collective bargaining.

\section{Testing of Hypothesis III}

$\mathrm{H}_{\mathrm{o}}$ : There is no significant relationship between awareness to ensure compliance with contents in collective bargaining

Questions 20,22, 23, 24, and 25 was chosen as relevant questions design to and analyzed in other to provide insight into this hypothetical statement thus;

\begin{tabular}{|l|l|l|l|l|l|l|l|}
\hline Question & SA & A & I & D & SD & & Total \\
\hline 20 & $61(\mathrm{a})$ & $12(\mathrm{~b})$ & $21(\mathrm{c})$ & & & & 94 \\
\hline 22 & $29(\mathrm{~d})$ & $12(\mathrm{e})$ & $10(\mathrm{f})$ & $13(\mathrm{~g})$ & $18(\mathrm{~h})$ & $12(\mathrm{i})$ & 94 \\
\hline 24 & $86(\mathrm{j})$ & $5(\mathrm{k})$ & $3(\mathrm{l})$ & & & & 94 \\
\hline 25 & $13(\mathrm{~m})$ & $18(\mathrm{n})$ & $26(\mathrm{o})$ & $13(\mathrm{p})$ & $8(\mathrm{q})$ & $15(\mathrm{r})$ & 93 \\
\hline Total & 189 & 47 & 60 & 26 & 26 & 27 & 375 \\
\hline
\end{tabular}

From the questionnaire

\begin{tabular}{|l|l|l|l|l|l|}
\hline SN & $\mathbf{O}$ & $\mathbf{E}$ & $(\mathbf{O}-\mathbf{E})$ & $\mathbf{O - E} / \mathbf{E}$ & $\mathbf{E}(\mathbf{O}-\mathbf{E} / \mathbf{E}) \mathbf{2}$ \\
\hline A & 6 & 22 & -16 & -0.7273 & 0.5290 \\
\hline B & 36 & 27.67 & 8.33 & 0.3010 & 0.0906 \\
\hline C & 3 & 1.67 & 1.33 & 0.7964 & 0.6343 \\
\hline D & 9 & 5.33 & 3.67 & 0.6886 & 0.4742 \\
\hline E & 6 & 3.33 & 2.67 & 0.8018 & 0.6429 \\
\hline F & 24 & 22 & 2 & 0.0909 & 0.0083 \\
\hline G & 30 & 27.67 & 2.33 & 0.0842 & 0.0071 \\
\hline H & 0 & 1.67 & -1.67 & -1 & 1 \\
\hline I & 6 & 5.33 & 0.67 & 0.1257 & 0.0158 \\
\hline J & 0 & 3.33 & -3.33 & -1 & 1 \\
\hline K & 36 & 22 & 14 & 0.6364 & 0.4050 \\
\hline L & 17 & 27.67 & -10.67 & -0.3856 & 0.1487 \\
\hline M & 2 & 1.67 & 0.33 & 0.1976 & 0.0390 \\
\hline N & 1 & 5.33 & 4.33 & 0.8124 & 0.66 \\
\hline O & 4 & 3.33 & 0.67 & 0.2012 & 0.0405 \\
\hline Chi Square & & & & & 5.6954 \\
\hline
\end{tabular}

\section{Determination of critical value:}

Degree of freedom $(\mathrm{df})=(\mathrm{n}-1)(\mathrm{r}-1)$

Where:

$$
\begin{aligned}
& \mathrm{n}=\text { column } \\
& \mathrm{r}=\text { Column }
\end{aligned}
$$

Degree of freedom $(\mathrm{df})=(5-1)(3-1)=(4)(2)=8$

That is 16 at 0.05 , then Chi Square Table $\left(\mathrm{X}^{2} \mathrm{Tab}\right)=15.507$

While Chi Square Calculated $\left(X^{2}\right.$ cal $)=5.6954$

\section{Decision Rule}

If $\mathrm{X}^{2}$ tab is greater than (>) $\mathrm{X}^{2}$ cal at 0.05 , accept Null $\left(\mathrm{H}_{\mathrm{O}}\right)$

Otherwise, reject Null $\left(\mathrm{H}_{\mathrm{O}}\right)$

From the above computation, Chi Square Table $\left(\mathrm{X}^{2} \mathrm{Tab}\right)$ at 15.507 is greater than Chi Square Calculated $\left(\mathrm{X}^{2}\right.$ cal $)$ at 5.6954 accept null hypothesis. Therefore, there is no significant relationship between awareness of workers and contents on collective bargaining agreements. 


\section{Summary, Conclusions And Recommendations}

This study examines the current status of collective bargaining, with particular focus on subjects and workers' right and the extent to which they are complied with and enforced as well as what can be done to ensure the compliance of subjects on collective bargaining in Total Nig. Plc.

In carrying out this research, the survey research technique was adopted using a combination of primary and secondary materials. To elicit information from the respondents, an open-ended questionnaire containing 25 items was employed in this research work. This was complemented by interview of key trade union officials and the management team. In all 94 questionnaires were given out to the respondents in their offices and places of work the total numbers of 94 questionnaires were personally retrieved by the research through the assistance of the chairman of the Petroleum and Natural Gas Senior Staff Association of Nigeria (Total Nigeria Plc Branch) and Human Resource Manager respectively.

\subsection{RECOMMENDATIONS}

Based on analysis of empirical data and secondary materials the major findings include:

There is an appreciable level of awareness of subjects on collective bargaining and workers rights in the population of the study. A great majority of them claimed to be aware of the subjects on collective bargaining and workers rights as unions and the management confirmed these through wide range of subjects' collective bargaining and rights identified by them.

The problem, however, lies in the inability of the unions to compel employers to comply with relevant provisions of the collective bargaining agreements. The situation is further aggravated by the prevailing economic situation in the country, which makes unions very vulnerable.

The level of compliance on the part of employer is very low. In fact, it would appear that employers are deliberately avoiding compliance. Taking advantages of the weak legal framework and vulnerability of workers in an unstable economic environment.

The prevailing reality in respect of subjects on collective bargaining and workers' rights is not because the union did not try. Within the limits imposed by law and the political and economic regimes, they tried to organize workers and defend them but were shortchanged by the hostility of employers.

However, the workers still strongly believe that the trade unions organizations are capable of protection and defending collective bargaining agreements. This is in spite of the challenges confronting the trade union movement.

The prevailing reality in respect of compliance with the subjects on collective bargaining and workers rights is not because the unions did not try. Of course, the unions need to promote inclusiveness and internal democracy in order to endear themselves more to workers.

The unions also need to continue to put interest of their workers as the major thing in the course of their negotiations and let the public know the rights of workers. This would help them to internalize these rights. Awareness on the part of the workers is likely to reduce the likelihood of infringement, while it may reduce the hostility of the consuming public. To complement the above, we strongly believe the human rights groups and activist should be interested in public interest litigation such that they can take up cases, on behalf of workers, against employers who routinely breach provisions of the relevant laws. The costs of litigation and negative publicity generated may also serve as a deterrent to the employers. In addition to litigation, advocacy on collective bargaining and workers' rights should take as a major plank of the work of the NGOs.

\subsection{CONCLUSIONS}

From the findings of this study, our conclusion is that the provisions of labour laws and international labour standards of the ILO in, and by, themselves are not enough guarantees for the protection of collective bargaining and as such, there is need to look beyond these instruments in protesting the rights of workers. Workers, their organizations and allies within the labour movement may need to adopt extra-judicial means, including political and social actions to defend the subjects on collective bargaining and workers' rights.

Finally, as long as the world panders to whims and caprices of operators and beneficiaries of the systems, the quest for ensuring that workers' rights and collective bargaining are respected will remain mirage. There is no reason why transnational corporations cannot observe prevailing standards in Nigeria, which in most cases are lower than what obtains in their home countries. 


\section{References}

[1] Ackers, P. and Wilkinson, A. (eds.)., (2003). Understanding Work and Employment: Industrial Relations in Transition, Oxford: Oxford University Press.

[2] Adewumi, F. and Adenugba, A., (2010). The State of Workers' Right in Nigeria: An Examination of the Banking, Oil and Gas and Telecommunication Sectors. Abuja. Friedrich-Ebert-Stiftung. www.fes-nigeria.org.

[3] Agbesinyale, P.K., (2003). Ghana's Gold Rush and the Regional Development: The case of Wassa West District, Dortmund: Spring Research Series.

[4] Akorsu, D. A., (2011). Labour Standards Application Among Multinational Domestic Firms in Ghana's Manufacturing Sector. Economic Annals, Volume LVI, No. 189/April-June 2011.

[5] Animashaun, O. and Shabi, O., (2000), Fundamentals of Industrial Relations: Issues and Theories. Lagos. Revised Edition, Hybrid Publishers.

[6] Blanpain, R., (2006). "Jurisdification of Industrial Relations: The Role of Labour Law in a Globalized Economy”. In M.S. Morley, P. Gunnigle and D.G Collings (eds.) Global Industrial Relations, London: Rutledge.

[7] Briscoe, D.R. and Schuler, R.S., (2004). International Human Resource Management: Second Edition, London: Rutledge.

[8] Brown, D.K., (2001). "Labour Standards: Where do they belong on the International Trade Agenda?", Journal of Economic Perspectives, 15:3, pp. 89-112.

[9] Dowling, P.J. and Welch, D.E., (2004). "International Human Resource Management: Managing People in a Multinational Context, Fourth Edition, London: Thompson.

[10] Baldwin, S., (2006). Organizational Justice, Institute for Employment Studies. http://www.employment-studies.co.uk. Dawson, C., (2002). Practical Research Methods, New Delhi, UBS Publishers' Distributors.

[11] Caves, R.E., (1993). Introduction: The Nature of Trans-National Corporations and their Activities. In UN Library of Transnational Corporations (eds.), The Theory of Trans-National Corporations, London. Rutledge.

[12] Chidi, O.C; Badejo, E.A. and Ogunyomi, O.P., (2010). Collective Bargaining Dynamic in the Upstream Oil and Gas Industry: The Nigerian Experience. Department of Industrial Relations and Personnel Management, University of Lagos.

[13] Collins, D. G., (2007). Multinational Corporations and Industrial Relations Research: A road less traveled. International Journal of Management Reviews, Volume 10, Issue 2.

[14] Edwards, T. and Kuruvilla, S., (2005). "International HRM: National Business Systems, Organisation Politics and the International Division of Labour in MNEs", International Journal of Human Resource Management, New York: McGraw Hill/Irwin.

[15] Fajana, S., (2005). Industrial Relations in the Oil Industry in Nigeria. Geneva. (ILO Working Paper in Sectoral Activities Programme). www.ilo.org.publns.

[16] Fajana, S., (2009). Industrial Relations and Collective Bargaining Trends in Nigeria. An ILO Commissioned Research Project. Geneva. www.ilo.org.publns.

[17] Fasan, C.O., (2011). Collective Bargaining and Corporate Strategy, Unpublished Manuscript, IRP: 802, Lagos State University, Nigeria.

[18] Gernigon, B; Odero, A; and Guido, H., (2000). ILO Principles Concerning Collective Bargaining. Geneva. http://www.ilo.org.publns.

[19] Gennards, J. and Ramsay, H., (2003). "Strategic International Labourism: MNEs and Labour in the Graphical Sectors" in W.N. Cookie (eds.) Multinational Enterprises and Global Human Resource Strategies. Westport, CA, Quotum.

[20] Gollbach, J. and Schulten, T., (2000). "Cross-border Collective Bargaining Networks in Europe" European Journal of Industrial Relations, 6: 161-79.

[21] Gunniegle, P., Collings, D. and Morley, M., (2006). "Adapting to Foreign Capital: Industrial Relations in American MNEs in Ireland" in A. Fernier, J. Quintanilla and C. Sanchez-Runde, Multinationals and the Construction of Transnational Practices: Convergence and Diversely in the Global Economy, London: Palgrave.

[22] Gordon, R., (1992). Basic Interviewing Skills. Hasca, IL: Peacock.

[23] Hasnat, B., (2001). Foreign Direct Investment and Workers Rights.

[24] Journal of Global Business Issues, 1.

[25] Holley, Jr. W. H.; Kenneth M. J. and Rogers S. W., (2005). The Labour Relations Process. USA: Thomson, south-west ILO., (2009). Collective Bargaining: Negotiating for Social Justice.

[26] High-level Tripartite meeting on Collective Bargaining, Geneva.

[27] Irene; (2000). Controlling Corporate Wrongs: The Liability of Multinational Corporations. Report of International IRENE Seminar on Corporate Liability and Workers' Rights held at the University of Warwick, Coventry, United Kingdom, 20 and 21 March, 2000.

[28] Jenkins, R., (1987). Trans-National Corporations and their Development: The Internationalization of Capital and the Third World. London: Methuen \& Co. Limited.

[29] Juravich, T. and Bronfenbrenner, K., (2003). "Out of the Ashes: The Steel Workers' Global Campaign at Bridgestone/Firestone" in W.N. Cookie (eds.) Multinational Enterprises and Global Human Resource Strategies, WestPoint, CA, Quorum.

[30] Kochan A. T., (2003, April). Collective Actors in Industrial Relations: What future? IIRA World Congress, Track 4, Rapporteur' Report. MIT Institute for Work and Employment Research and MIT Workplace center.

[31] Kothavi, C.R., (1985). Research Methodology: Methods and Techniques, New Delhi, Wiley Eastern Limited.

[32] Kumar, Ranjit., (2005). Research Methodology-A Step-by-step Guide for Beginners, (2 ${ }^{\text {nd }}$ Ed.) Singapore, Pearson Education.

[33] Labaw, Patricia J., (1998). Advanced Questionnaire Design. Cambridge, MA: ABT Books.

[34] Marginson, P., Armstrong, P., Edwards, P. and Purcell, J., (1995).

[35] "Managing Labour in the Global Corporation: A survey based analysis of Multinationals operating in the UK", International Journal of Human Resource Management, 6 pp. 6, 2-19. 
[36] Meard, G., (2006). "Multinationals' heaven? Uncovering and Understanding workers responses to multinational companies in post-communist Central Europe”, International Journal of International Human resource Management, 17: 00. 1366-78.

[37] Michael M.C; Gunnigle P; Javier Q. and Anne T., (2000). Between home and host Country: Multinationals and employment relations in Europe. Industrial Relations Journal, Oxford, U.K. Blackwell Publishers Ltd.

[38] Munck, R., (2002). Globalization and Labour: The New “Great Transformation”, London: Zed books Limited.

[39] Nigerian Labour Congress., (2007). Policy Document. Retrieved from www.nlc.org/publns.

[40] Nnamdi, Asika., (1990). Research Methodology in the Behavioural Science. Ikeja. Longman.

[41] Ogunniyi, O., (1991). Nigerian Labour and Employment Law in Perspective. Lagos. Folio Publishers.

[42] Okene, O.V.C., (2010). Collective Bargaining, Strikes and the Quest for Industrial Peace in Nigeria. Retrieved from www.ilo.org/public/english/burea/inf/download/magazine/pdf/may35.pdf.

[43] Rodgers, G., (2002). Decent works as a goal for the Global Economy.

[44] Geneva: International Labour Organization/Training, Productivity and Decent Works.

[45] Rojot, J., (2006). "International Collective Bargaining" in M.J. Morley; P.

[46] Gunnigle and D.G. Collings (eds.) Global Industrial Relations, London: Rutledge.

[47] Roots, E.R., (1994). Entry Strategies for International Market. San Francisco: John Wiley \& Sons.

[48] Schutt, R. K., (1996). Investigating the Social World (The Process and Practice of Research), London, Sage Publication Company.

[49] Standing, G., (1997). Globalization, Labour Flexibility and Insecurity: The Era of Market Regulation. European Journal. Industrial Relations, 3, 7-37.

[50] Tapiola, Kavi., (2000, July). Core Labour Standards and Globalization. A presentation at the Asian Development Bank, Manila.

[51] Voss, P.B., (2001). “An IR Perspective on Collective Bargaining”, Human Resource Management Review, 11, 487-503.

[52] Zhang, M. Edwards, T. and Edwards, C., (2006). Internationalization and Developing Countries: The Case of China. In: Edwards, T. \& Rees, C. (eds.), International Human Resource Management: Globalization, National Systems and Multinational Companies. London: Pearson Education Limited. 